\title{
PHYTOCHEMICAL AND ANTIMICROBIAL STUDIES ON GARCINIA LATTISSIMA MIQ. FRUIT EXTRACT
}

NENENG SITI SILFI AMBARWATI ${ }^{1,2}$, BERNA ELYA ${ }^{1 *}$, AMARILA MALIK ${ }^{1}$, MUHAMMAD HANAFI ${ }^{3}$

${ }^{1}$ Faculty of Pharmacy, Universitas Indonesia, Depok 16424, Indonesia. ${ }^{2}$ Faculty of Engineering, Jakarta State University, Jl. RawamangunMuka, East Jakarta 13220, Indonesia. ${ }^{3}$ Centre for Chemistry, Indonesian Institute of Sciences, Serpong, Banten, Indonesia Email: berna.elya@gmail.com

Received: 17 March 2017, Revised and Accepted: 13 April 2017

ABSTRACT

Objective: The present investigation was aimed to explore the phytoconstituents present in the fruit part of Garcinia lattissima Miq. and their antimicrobial efficacy.

Methods: The preliminary phytochemical constituents were qualitatively analyzed using the standard procedures described in Materia Medica Indonesia. Antimicrobial screening was performed using disc diffusion and dilution methods.

Results: Phytochemical screening of different extracts of $G$. lattissima Miq. fruits revealed the presence of tannins, saponins, flavonoids, and alkaloids, and the results are shown in Table 1 . The ethyl acetate and methanolic extracts of G. lattissima Miq. fruits showed antimicrobial activity, and the n-hexane extract failed to prove the inhibition against the selected pathogens.

Conclusion: The results of the phytochemical and bio-efficacy study revealed most valuable information and also support the continued sustainable use of G. lattissima Miq. fruits in the traditional system of medicine.

Keywords: Garcinia lattissima Miq., Antimicrobial, Phytochemical, Tannins, Saponins, Flavonoids, Alkaloids.

(C) 2017 The Authors. Published by Innovare Academic Sciences Pvt Ltd. This is an open access article under the CC BY license (http://creativecommons. org/licenses/by/4. 0/) DOI: http://dx.doi.org/10.22159/ajpcr.2017.v10i7.18528

\section{INTRODUCTION}

This study proposed the existence of active phytochemical compounds and to explore the antimicrobial activity in different solvents of Garcinia lattissima Miq. fruit extract.

Plants as living chemical factories provide a vast number of important chemical substances that display a variety of biological actions. About 35,000 (some estimate up to 70,000) plant species are used worldwide for medicinal purposes. Researchers have investigated $<0.5 \%$ of these for their phytochemical and pharmacological potentials. More latterly there has been a recovery of attracting in the medicinal possibles of therapeutic trees as antimicrobials.Also, others species have been researchedtonew antimicrobials potential of plant species [1]. The Clusiaceae or Guttiferae family contains 27 genera and 1,090 species, mostly restricted to lowland tropics [2]. Of which, Garcinia genus includes about 400 species of evergreen trees or shrubs, occurring from West Africa across tropical Asia to the Fiji Island [3], and most of these contain xanthones [2].

Garcinia latissima Miq. commonly known as Dolomagota (Maluku, Indonesia) and the gland of the plant used as cure wound [4]. G. lattissima Miq. is distributed in East Sepik, Eastern Highlands, West Sepik, Southern Highlands, Western Highlands, Madang, Western Morobe, Milne Bay, Central Gulf, Britain, and Papua Islands [5]. In Indonesia, G. lattissima Miq. grows in Seram Island, Maluku, and in Papua, but it has been cultivated in the Bogor Botanic Gardens [6]. Constituents of the stem bark ethanol extract of G. lattissima Miq. gathered in Papua New Guinea Central Province were latisxanthone-A, latisxanthone-B, latisxanthone-C, and latisxanthone-D [7]. Latisxanthone is classified as pyranoxanthone. The G. lattissima Miq. stem bark ethanol extract collected in Papua New Guinea (Central Province) showed good antibacterial activity (inhibition zone was 8-12 $\mathrm{mm}$ ) against Staphylococcus aureus and Bacillus subtilis (Gram-positive bacteria) and moderate activity (inhibition zone was 4-7 mm) against Escherichia coli [8]. With this knowledge, the present investigation deals with the phytochemical analysis and antimicrobial efficacy of G. lattissima Miq.

\section{MATERIALS AND METHODS}

\section{Plant collection and extraction}

G. lattissima Miq. fruits were collected and identified from the Center for Plant Conservation Bogor Botanical Gardens, Indonesian Institute of Sciences (LIPI), West Java, Indonesia. The sliced fruits were shadedried at room temperature and powdered coarsely using a mechanical homogenizer. Powdered plant material was extracted by multilevel maceration using various solvents such as n-hexane, ethyl acetate, and methanolic in a row. The filtrate of the extracts was evaporated to dryness under reduced pressure using a rotary evaporator. The extraction yields were collected, weighted, and stored at $4^{\circ} \mathrm{C}$ before use [1]. The extraction yield can be calculated by

extraction yield $(\%)=\frac{\text { dry weight of extract }}{\text { dry weight of plant powder }} \times 100[9]$

Phytochemical and antimicrobial activities

The qualitatively analyzed phytochemical constituents used in the standard procedures were described by Fransworth and methods from Materia Medica Indonesia Volume VI [10-11]. Antimicrobial screening was performed by disc diffusion method [12]. Two Gram-positive bacteria (B. subtilis ATCC 6633 and S. aureus ATCC 25923), two Gram-negative bacteria (Pseudomonas aeruginosa ATCC 27853 and E. coli ATCC 25922), and two fungi (Candida albicans and Trichophyton mentagrophytes). The zone of inhibition against the selected pathogens was determined and recorded. The standard antibiotics used as positive control were gentamycin for $S$. aureus, erythromycin for B. subtilis, ciprofloxacin for $P$. aeruginosa, and amoxicillin for $E$. coli. The first step of the zone of 
Table 1. Phytochemical screening of G. lattissima Miq. fruits

\begin{tabular}{lllll}
\hline Tests & Reagents used & n-hexane extracts & Ethyl acetate extracts & Methanolic extracts \\
\hline Tannins & Acidic FeCl & - & - & + \\
& Gelatin & - & - & + \\
Saponins & Frothing test & + & - & - \\
Flavonoids & HCl+Mg turnings & - & + & + \\
Anthraquinones & Borntrager's & - & - & - \\
Terpenoids & $\mathrm{H}_{2} \mathrm{SO}_{4}$ & - & - & - \\
Alkaloids & Dragendorff's & - & - & - \\
& Mayer's & - & + & - \\
& Bouchardat's & - & + & \\
\hline
\end{tabular}

Phytochemical screening +: Intensity reaction, -: Non-detected, G. lattissima: Garcinia lattissima

inhibition used crude extracts (100\%) [13]. The positive results from that did the area of inhibition with $2 \%$ extracts in DMSO. These methods were in triplicate. The assay of minimum inhibitory concentration (MIC) and minimum bactericidal concentration (MBC) performed for extracts gave a zone of inhibition of $2 \%$ extracts. To determine the MIC test used the broth dilution method, and to determine the minimum bactericidal assay by plating out onto each appropriate agar plate [14]

\section{RESULTS AND DISCUSSION}

Fruits from G. lattissima Miq. for this research are shown in Fig. 1.

The results of extraction yields from G. lattissima Miq. fruits are shown in Table 2.

The screening of phytochemical for different extracts of $G$. lattissima Miq. fruits revealed the existence of different chemical compounds of tannins, saponins, flavonoids, and alkaloids, and Table 1 represents the results. Flavonoids and alkaloids (using Dragendorff's and Bouchardat's reagents) were present in ethyl acetate extracts of $G$. lattissima Miq. The methanolic extracts of $G$. lattissima Miq. demonstrated the presence of tannins and flavonoids. The n-hexane excerpts from G. lattissima Miq. illustrated the presence of saponins only.

The antimicrobial efficacy from n-hexane, methanolic, and ethyl acetate extracts $(100 \%)$ of $G$. lattissima Miq. from this research are shown in Table 3. The inhibition zone diameters $\geq 10 \mathrm{~mm}$ were shown by the G. lattissima Miq. fruits' ethyl acetate extracts opposed to P. aeruginosa and B. subtilis and the methanolic extracts of G. lattissima Miq. fruits opposed to $S$. aureus, P. aeruginosa, and B. subtilis. The n-hexane extracts of $G$. lattissima Miq. fruits against B. subtilis and the ethyl acetate extracts of G. lattissima Miq. fruits opposed to E. coli and S. aureus showed inhibition area diameter $<10 \mathrm{~mm}$. Methanolic extracts of G. lattissima Miq. fruits against E. coli., C. albicans, and T. mentagrophytes were resistant to all the extracts.

Table 4 shows the results of the antibacterial activities of $2 \%$ G. lattissima Miq. fruits' extracts in DMSO. The antibacterial activity has been observed only in the G. lattissima Miq. fruits' ethyl acetate and methanolic extracts against the selected bacterial assay. The $\mathrm{n}$-hexane extracts were unsuccessful to give the inhibition against the bacterial assay. This research used the positive control with commercially available standard antibiotic disc (erythromycin for B. subtilis, gentamycin for S. aureus, and ciprofloxacin for P. aeruginosa). The conventional medicine showed positive results against all the tested bacteria. The ethyl acetate extracts (2\%) of G. lattissima Miq. fruits showed the maximum zone of inhibition against $P$. aeruginosa $(9.82 \pm 0.978 \mathrm{~mm})$ and then B. subtilis $(9.62 \pm 0.431 \mathrm{~mm})$. The methanolic extracts $(2 \%)$ of $G$. lattissima Miq. fruits showed the highest zone of inhibition against $S$. aureus $(9.97 \pm 0.448 \mathrm{~mm})$ and then $B$. subtilis $(9.53 \pm 0.416 \mathrm{~mm})$ and P. aeruginosa $(8.22 \pm 0.506 \mathrm{~mm})$.

Table 5 shows the results of dilution assay of extracts' antimicrobial activities. The results show that MIC and MBC of the methanolic
Table 2: The average of extraction yields from the result of multilevel maceration extraction from $G$. lattissima Miq. fruits

\begin{tabular}{lll}
\hline Solvents & Yield (\%) & Average (\%) \\
\hline n-hexane & 9.010 & $8.9093 \pm 0.4123$ \\
& 9.262 & \\
Ethyl acetate & 8.456 & $2.7640 \pm 0.7217$ \\
& 2.414 & \\
Methanol & 2.284 & $16.5640 \pm 1.9201$ \\
& 3.594 & \\
& 18.520 & \\
& 14.682 &
\end{tabular}

Table 3: Antibacterial ability of $G$. lattissima Miq. fruits' extracts $(\mathbf{1 0 0 \% )}$

\begin{tabular}{llll}
\hline Organisms & \multicolumn{3}{l}{ Zone of inhibition (mm) } \\
\cline { 2 - 4 } & Methanolic & Ethyl acetate & n-hexane \\
\hline B. subtilis & ++ & ++ & + \\
S. aureus & ++ & + & - \\
P. aeruginosa & ++ & ++ & - \\
E. coli & + & + & - \\
C. albicans & - & - & - \\
T. mentagrophytes & - & - & - \\
\hline
\end{tabular}

++ : Inhibition zone diameter $\geq 10 \mathrm{~mm},+$ : Inhibition zone diameter $<10 \mathrm{~mm},-$ : No inhibition zone, G. lattissima: Garcinia lattissima, B. subtilis: Bacillus subtilis, S. aureus: Staphylococcus aureus, P. aeruginosa: Pseudomonas aeruginosa, E. coli: Escherichia coli, C. albicans: Candida albicans,

T. mentagrophytes: Trichophyton mentagrophytes

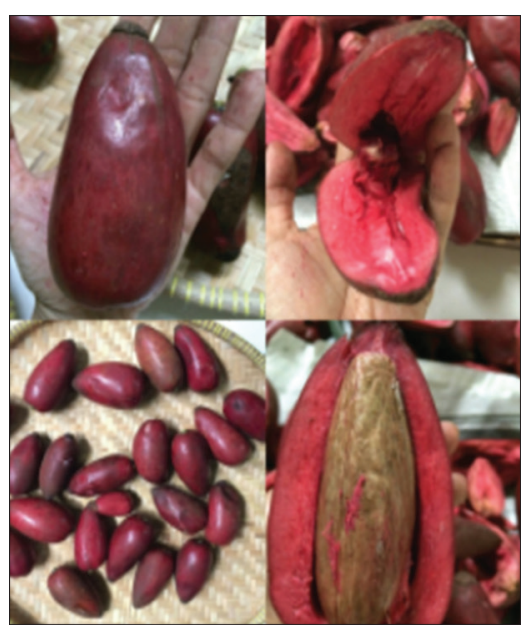

Fig. 1. Fruits of Garcinia latissima Miq. 
Table 4: Antibacterial activities from 2\% G. latissima Miq. fruits' extracts in DMSO using agar diffusion method

\begin{tabular}{lllll}
\hline Bacteria & \multicolumn{2}{l}{$\begin{array}{l}\text { The mean } \pm \text { SD of diameter of inhibition } \\
\text { zone }(\mathbf{m m})\end{array}$} \\
\cline { 2 - 5 } & n-hexane & $\begin{array}{l}\text { Ethyl } \\
\text { acetate }\end{array}$ & Methanolic & $\begin{array}{l}\text { Antibiotic } \\
\text { standard }\end{array}$ \\
\hline B. subtilis & 0 & $9.62 \pm 0.431$ & $9.53 \pm 0.416$ & $21.08 \pm 1.928$ \\
S. aureus & 0 & 0 & $9.97 \pm 0.448$ & $23.70 \pm 1.928$ \\
P. aeuginosa & 0 & $9.82 \pm 0.978$ & $8.22 \pm 0.506$ & $21.88 \pm 0.511$ \\
\hline
\end{tabular}

Antibiotic standard: Erythromycin $15 \mu \mathrm{g}$ for B. subtilis, gentamycin

$10 \mu \mathrm{g}$ for $S$. aureus, ciprofloxacin $5 \mu \mathrm{g}$ for P. aeruginosa,

G. latissima: Garcinia latissima, B. subtilis: Bacillus subtilis,

S. aureus: Staphylococcus aureus, P. aeruginosa: Pseudomonas aeruginosa

DMSO: Dimethyl sulfoxide

Table 5: MBC and MIC from the G. latissima Miq. fruits' methanolic and ethyl acetate extracts (in ppm)

\begin{tabular}{lllllllll}
\hline \multirow{2}{*}{ Solvents } & \multicolumn{2}{l}{ B. subtilis } & & \multicolumn{2}{l}{ S. aureus } & & \multicolumn{2}{l}{ P. aeruginosa } \\
\cline { 2 - 3 } & MIC & MBC & & MIC & MBC & & MIC & MBC \\
\hline Ethyl acetate & 2500 & 5000 & & - & & 5000 & 5000 \\
Methanolic & 1250 & 5000 & & 5000 & 10000 & & 2500 & 2500 \\
\hline
\end{tabular}

G. latissima: Garcinia latissima, B. subtilis: Bacillus subtilis,

S. aureus: Staphylococcus aureus, P. aeruginosa: Pseudomonas aeruginosa,

MBC: Minimum bactericidal concentration, MIC: Minimum inhibitory

concentration

extracts and the ethyl acetate extracts opposed to $P$. aeruginosa, B. subtilis, and S. aureus were different. Ethyl acetate extracts and methanolic extracts of $G$. lattissima Miq. fruits were active against B. subtilis (MIC=2,500 ppm and 1,250 ppm, respectively) and against $P$. aeruginosa ( $\mathrm{MIC}=5,000 \mathrm{ppm}$ and $2,500 \mathrm{ppm}$, respectively). The methanolic extracts of $G$. lattissima Miq. fruits were active against $S$. aureus (MIC $=5,000 \mathrm{ppm}$ ). The ethyl acetate extracts of $G$. lattissima Miq. fruits were not tested for Gram-positive bacteria $S$. aureus because they did not give inhibition zone in $2 \%$ G. lattissima Miq. fruits' extracts assay. The methanolic extracts have more powerful activity of antimicrobials as contrast to ethyl acetate extracts. The results of the study indicate that G. lattissima Miq. fruits' extracts could be useful for antibacterial uses [15].

\section{CONCLUSION}

This study indicated that the methanolic extracts of G. lattissima Miq. fruits had the highest rendemen than the others. The methanolic extracts consist of tannins and flavonoids, qualitatively. The ethyl acetate extracts include flavonoids and alkaloids, and the hexane extracts consist of saponins only. The antimicrobial activity showed that the methanolic extracts of G. lattissima Miq. fruits had the best result than the others.

\section{ACKNOWLEDGMENT}

The authors thank Universitas Indonesia through HIBAH PITTA 2017 that supported this study. We are grateful to Plant Conservation Botanical Gardens Center, Indonesian Institute of Sciences, that provided researched fruits and confirmed authenticity of the fruits.

\section{REFERENCES}

1. Johnson M, Kalaiarasi V, Sivaraman A, Janakiraman N, Babu A, Narayani M. Phytochemical and antibacterial studies on Aristolochia tagala Cham. World J Pharm Res 2014;3(2):2172-8.

2. Stevens PF. The families and genera of fascular plants. In: Flowering Plants. Vol. 9. Berlin, Heidelberg: Springer-Verlag; 2007. p. 48-66.

3. Ramage CM, Sando L, Peace CP, Carroll BJ, Drew RA. Genetic diversity revealed in the apomictic fruit species Garcinia mangostana L. (Mangosteen). Euphytica 2004;136(1):1-10.

4. Eisai P. Medicinal Herb Index in Indonesia. $2^{\text {nd }}$ ed. Indonesia: P.T. Eisai; 1995. p. 71.

5. Conn B, Damas K. PNGTreesKey-Garcinia latissima Miq. In: Annales Musei Botanici Lugduno-Batavi. Vol. 1. New South Wales, Papua New Guinea: National Herbarium; 1863.

6. Sari R, Ruspandi, Ariati SR. An Alphabetical List of Plant Species Cultivated in the Bogor Botanic Gardens. Bogor: LIPI; 2010.

7. Ito C, Miyamoto Y, Nakayama M, Kawai Y, Rao KS, Furukawa H. A novel depsidone and some new xanthones from Garcinia species. Chem Pharm Bull 1997;45(9):1403.

8. Rao KS. Antibacterial activity of some medicinal plants of Papua New Guinea. Int J Pharmacogn 1996;34(3):223-5.

9. Yin NG, Abdullah S, Phin CK. Phytochemical constituents from leaves of Elaeis guineensis and their antioxidant and antimicrobial activities. Int J Pharm Pharm Sci 2013;5(4):137-40.

10. Fransworth NR. Biological and phytochemical screening of plants. J Pharm Sci 1995;22(3):226-76.

11. Depkes RI. Materia Medika Indonesia. Vol. VI. Jakarta: Departemen Kesehatan Republik Indonesia; 1995.

12. Bamas SS, Kingsley SJ, Sankaranarayanan S. Antibacterial activity of different phytochemical extracts from the leaves of T. Procumbens. Linn.: Identification and Mode of action of the terpenoid compound as antibacterial. Int J Pharm Pharm Sci 2012;4:557-64.

13. Mathew S. An evaluation of the antimicrobial activity of various concentrations of Ocimum sanctum against various species of bacteria: An in vitro study. Int J Adv Appl Sci 2014;3(1):33-6.

14. Jeong MR, Kim HY, Cha JD. Antimicrobial activity of methanol extract from Ficus carica Leaves against oral bacteria. J Bacteriol Virol 2009;39(2):97-102.

15. Sanches NR, Cortez DA, Schiavini MS, Nakamura CV, Dias-Filho BP. An evaluation of antibacterial activities of Psidium guajava (L.). Braz Arch Biol Technol 2005;48(3):429-36. 